\title{
PECULIARITIES OF JEWISH PRAYERFUL ESTABLISHMENT APPEARANCE IN TOMSK IN THE MID 19TH - IN THE EARLY 20TH CENTURY
}

\author{
Oksana S. Ulyanova ${ }^{*}$, Galina S. Kazantseva ${ }^{2}$ and Sonya V. Miroshkina ${ }^{3}$ \\ ${ }^{1}$ Assoc. Prof., PhD, Tomsk Polytechnic University, Russian Federation, shamaim_7@mail.ru \\ ${ }^{2}$ Assoc. Prof., Tomsk Polytechnic University, Russian Federation, kgs@tpu.ru \\ ${ }^{3}$ Student, Tomsk Polytechnic University, Russian Federation, c.comik@yandex.ru \\ ${ }^{*}$ Corresponding author
}

\begin{abstract}
The article deals with some aspects of religious institutions of a Jewish community in Tomsk in the mid-19th in the early 20th century. In different national surroundings a prayerful house becomes the center of Jewish Diaspora habitation and a guarantee of ethnic self-consciousness and traditional culture reservation. Simultaneously Russian legislation and regional life peculiarities affect greatly the opportunities of the community existence as an independent social structure. These processes are contemplated in the article.
\end{abstract}

Keywords: Jewish community, synagogue, Tomsk, Siberia.

\section{INRTODUCTION}

The investigation of the mechanisms of ethnic self-consciousness guarantee reservation and the nation unity which are a popular subject for analysis today can be carried out using the materials in history of a Jewish community in Siberia in the mid-19th - in the early $20^{\text {th }}$ century. Synagogues and prayerful houses construction history and their functioning in Siberia are discussed in the article.

The choice of a prayerful house as a spiritual life center of a Jewish community is accounted for by the fact that it is the house which has become a guarantee of Jewish cultural traditions and ethnic selfconsciousness reservation in different national surroundings.

This unique ethnic minority experience and different national surroundings are of great importance particularly nowadays when against the background of socio-economic and political crisis throughout the world, some political groups attempt linking these problems with the specific nation vital activity, but consequently the number of international conflicts increases.

As a result, one of the vital problems of contemporary Russia is the task to preserve it as a poly ethnical state on the bases of tolerance and democracy, building civilized relationships among people with different cultures and religions.

Negative ethnic stereotypes, national prejudices occur under the conditions of both lack of objective information and prosaic lack of knowledge of history and culture of people living nearby and widely 
presented in different spheres of social life of contemporary Russia: economics, politics, science and culture.

In the meantime, ignoring or misunderstanding all the complexity and contradictoriness of relationship history among nations leads to forming wrong ideas about their national peculiarities, phobias, which are often used for definite political aims.

\section{PECULIARITIES OF JEWISH PRAYERFUL ESTABLISHMENT APPEARANCE IN TOMSK}

\subsection{Materials and Methods}

The materials for this article were archive sources from State archive of Tomsk Region grouped in different funds: Tomsk Gubernia administration fund, Tomsk Gubernia district fund and Tomsk Gubernia construction commission as well as some data from Siberian periodicals. Besides, the code of legislative acts of the Russian Empire in the mid-19th - in the early 20th century, regulating prayerful institutions religious life and activity was analyzed. In addition to this, some research by contemporary scholars who study Jewish community history in Siberia, such as L.V. Kalmina (Kalmina, 2003, 164 p.), Yu.M. Muchnik (Muchnik, 1997, 59 p.), etc. as well as works by researchers of the early 20th century: Yu. Ostrovsky (Osrtovsky, 1911, 205 p.), G.Ya. Tsam (Tsam, 1909, 21 p.), etc. were used.

The results presented in the article were obtained relying on the following common research methods: description, comparison and analysis. The system approach due to which a Jewish community in Tomsk is considered to be a self-regulated system of interrelated and mutually specified elements has become a methodological base of the article. The civilizational approach is also used. The Jewish Tomsk population was under Russian civilization sphere of influence with its socio-economic, political and cultural features. Tomsk Jewish Diaspora is considered through the prism of preserved socio-cultural and spiritual elements of Hebrew civilization which accounts for using the main principles of the civilizational approach. When using it, however, it should be kept in mind that some elements of Hebrew civilization were modified; they included some Russian civilization traits. Moreover, it is on the example of Tomsk Jewish community vital activity that this influence is especially traced in accordance with involving a large number of Jews into social life than inside Pale of settlement.

\subsection{Results}

The process of prayerful houses appearance, rabbinate establishing in Tomsk were complicated and took a long time. Demand in establishing a prayerful house and an official permission for its activity did not always coincide, which was especially the case not only for Tomsk but for most Siberian Jewish communities.

Consequently, the account of a Jewish community existence in Tomsk can be started not from the time of the first prayerful house construction (1850), but from the time of submitting the petition about establishing a prayerful school, that is when the Jews become aware of the need for joining up around the confessional center (in Tomsk - from 1835).

A synagogue or a prayerful house establishing in the $19^{\text {th }}-20^{\text {th }}$ centuries was possible only with the provincial authority permission, and outside the Pale of Settlement - by provincial authorities proposing with the permission of Minister of Internal Affairs (Collection of Laws, 1896, p. 236). According to the legislation, it was permitted to establish one prayerful school "in any town or a settlement where the number of houses is not more than thirty", and in the places where the number of houses was not more than eighty, it was possible to open a synagogue. In case there were more than eighty houses, it was permitted to open one school for every thirty houses and one synagogue for every eighty houses. But Jewish synagogues and a prayerful school should be located in the same street or a square at a distance of not fewer than 100 yards away from Orthodox churches, whereas in the neighboring street - not fewer than 50 yards (The Code of laws' of the Russian Empire, 1844, № 18029, p. 418).

In fact, a synagogue must be a kind of institutions, only to meet religious needs without carrying out other social functions, as in both synagogues and prayerful schools it was strictly forbidden to hold all kinds of meetings "for other activities apart from prayer and belief rite performing, and keeping other different things apart from those which belonged to divine service and metric books" (Collection of Laws, 1896, p. 237). Meanwhile the Jews did not distinguish a synagogue, a prayerful school and a prayerful house considering all of them only as an institute to meet religious needs (Unpublished Doc. 996, p.3). In ordinary life, official 
authorities themselves did not always tell the difference in terminology, according to the Tomsk police chief, in 1913, there were three synagogues, though, in fact, there was only one synagogue - a choral one - and two prayerful houses.

In October 1835, Tomsk governor was reported with a petition from a Tomsk tradesman named Abram Zhukov and some Jewish villagers of Tomsk district informing him about setting up a prayerful house in Tomsk and appointing a local rabbi Nukhim Froimovitch Vuinsky who was able to read and write in Russian, apart from a Jewish dialect", known for "his respectable" behavior, and a bursar - a peasant coming from the Jews named Mordko Karnovsky (Unpublished Doc. 35, p. 4). However, the petition was not satisfied because on May 15, 1837, some rules were issued due to which a Jewish settlement in Siberia was "strongly and forever” forbidden ('The Code of laws' of the Russian Empire, 1838, № 10242, pp. 324 - 325) and making references on these rules, the Tomsk governor did not permit them to open a prayerful house and did not appoint the rabbi (Ulyanova, 2011, p. 9).

The first synagogue in Tomsk was opened only in 1850. It was a one-story wooden building like the majority of synagogues in Siberia quite unattractive in appearance, but according to Yu. Ostrovsky, it was an object of community people pride. It was located in Peskov district, in Magistratskaya Street, next to the police department in Sennaya Street (Osrtovskiy, 1911, p. 39).

It was not until January 19, 1863, according to the high order, the Jews living outside the Pale of Settlement were permitted to invite rabbis who were responsible for keeping metric books in accordance with the Department spiritual work of foreign confession circular (Unpublished Doc. 1459, p. 1).

On September 4, 1901 an announcement concerning collecting donation for a new synagogue construction was published in the newspaper "The Siberian Life" (The Siberian Life, 1901, p. 23). As early as 1902 in the place of the former synagogue, a stone one named "Choral" was erected. The building was a big one constructed in a retrospective style of the $20^{\text {th }}$ century. It had a lancet arch of Oriental type, windows framed with small columns. Besides, there was a decorative small tower. The building composition was crowned with hexagram Star of David. During the service it could hold up to 800 people. In the far end of the hall located on the first floor and intended for male prayers, there was the Ark of the Covenant where Thora scrolls were kept. The second floor was intended for female prayers. The choir consisting of 12 boys participated in performing the ceremony (Unpublished Doc. 235, p 18). Choral synagogue consecration which became the religious life center was held on September 15, 1902 (Kutilova, Nam, Naumova and Safronov 1999, p. 24).

In 1859 Tomsk second-guild merchant M. Kaminer by name submitted the petition to build a temporary prayerful school at his own expenses on the plot of the ground bought from the tradesman named Baturin. $A$ letter and necessary constructing drafts for the future building front were attached to the petition as a support. When considering the petition, it turned out that in Tomsk there were more than 70 houses belonging to the Jews, that plot of the ground located within legal distance from the Orthodox Church. As a result, M. Kaminer's petition was satisfied on May 22, 1859 and a second prayerful school came into being in Tomsk (Unpublished Doc. 235, pp. 3 - 5).

Tomsk rabbi B. Levin submitted the petition to Tomsk provincial construction commission asking for permission to move the prayerful school to the other place, a specially bought one (Unpublished Doc. 1789, pp. 1 - 2). With the governor's permission, the prayerful house was located in Podgorny lane (between Dvoryanskaya and Pochtamskay streets). It was a two-story wooden building on a stone foundation (Unpublished Doc. 1788 pp. 1a - 1zh). Like the former school, it was also named "Kaminerskaya" after Michail Kaminer. In the new school back yard, there was also the first in Tomsk mikvah - a small reservoir for the ritual washing and due to the tradition part of the water must come into it from atmospheric precipitates. On May 13, 1895 on account of "persistent" necessity, Kaminerskaya prayerful school spiritual administrative board made a request about the school reconstruction. The permission for the school reconstruction was received with a condition of declaring the necessary sum of money and the source of its replenishment (Unpublished Doc. 3356. pp. 1-2).

The emergence of one more religious building in Tomsk was connected with Tomsk cantonists' activity. Forming a noticeable part of Tomsk Jewish community, they experienced the demand for their religious needs satisfaction. In spare time after the service, on Saturdays and holidays, soldiers attended Kaminerskaya synagogue situated next to the barracks where, according to cantonist school-leaver's memory, G. Ya. Tsam, they "were not warmly welcomed" (Tsam, 1909, p. 3). After they were offered to read Thora commandments in a changing room on the occasion of a newborn Moisey Gurevitch's son's 
circumcision, the soldiers decided to set up a separate prayerful school. In 1864 they began collecting donations to write Sefer-Thora synagogue manuscript scrolls. In the summer 1865 they collected 150 rubles and received the scroll. In the autumn 1865 a temporary prayerful school began working in Zateevsky lane in a woman's house. Gercel Tsam became the first churchwarden in it. The Jews living in Soldatskaya settlement also attended the new prayerful school. The school appeared to be cramped but the income afforded to begin constructing a permanent prayerful school building. A plot of land, under G. Ya. Tsam's name, was bought in Netchaevskaya Street and Zateevsky lane crossing, on which a permanent building was constructed in 1872.

Gradually, a military-prayerful school was settling down. A merchant Shmul Volobrinsky donated a library of Talmudic books and his sons - Mojshe and Mordhe - a suitable bookcase. A merchant Grigory Haymovitch bought a hanging 3-decked type silver chandelier for 32 candles. In 1886 part of the constructions attached to the school was demolished, and a wooden one-story building to meet the prayerful school needs was erected in this place (Unpublished Doc. 714, p. 6a)

In 1906 the school building suffered greatly from the fire and they made a decision to reconstruct it. By August 1907 the reconstruction was finished. The new building was erected in the Mauritanian style on stone foundation. The millwork of doors and windows were decorated with wooden carving. Thora scroll imprint was placed on the front doors and the Stars of David were written into the wooden ornament decorating the windows. The roof was crowned with three nice domes. In memory of the initiators, a new prayerful school received the name "Soldatskaya".

In 1889 Tomsk governor received a petition from exiled Jews living in Tomsk about setting up a synagogue. It was offered to name it "Aleksandrovskaya" in memory of saving Alexander III from perishing during the train crash on October 17, 1888. The exiled motivated their request by Tomsk tradesmen and merchants' "hostile relation" to them, which was shown even "in removal them from the synagogue during praying service" (Unpublished Doc. 996, p. 2). Considering the petition, it appeared that there was no place for construction, besides there were no drafts for the front. Moreover, there was one synagogue and two prayerful houses for 120 Jewish houses in the town, so that according to current laws, constructing some more new cultural buildings could not be allowed.

However, Provincial government admitted the fact that 'local Jews' hostility to the exiled, though not shown in removal from prayerful buildings, nevertheless is quite possible, and in whatever it might be, offends them straining the relations". Despite the positive solution this prayerful school, for unknown reasons, was never built.

\subsection{CONCLUSION}

To sum it up, it can be noted that the history of opening prayerful buildings in Tomsk reflects two tendencies. On the one hand, the desire of the Jews, cut off from the Pale of Settlement and found themselves in Siberia in different ways, is revealed in keeping their religious traditions, national self-consciousness. It was a prayerful house that became the center of religious life, uniting the Jews around itself. However, in Tomsk owing to social heterogeneity of ethno confessional diaspora including the following strata - descendants of the first settlers-old residents in the person of merchants and tradesmen, Jews-soldiers and exiled Jews, comparatively recently settling, some religious centers came into being. Social gradation here was registrated taking into consideration two criteria - prosperity and the settling length in Tomsk. Contradiction presence between them promoted the development inside the community for influence in a religious sphere. As a result, a great role was played by a rabbi personality to reconcile the conflicts.

\section{REFERENCE LIST}

Collection of Laws of the Russian Empire in 16 Volumes (1896). Vol.11. Part.1.

Kalmina, L. V. (2003). Jewish communities of Eastern Siberia (mid 19th - February, 1917).

Kutilova, L. A., Nam, I. V., Naumova, N. I., and Safronov, V. A. (1999). Chronicle of social and cultural life. $1885-1919$.

Muchnik, Yu. M. (1997). From the history of Jews in pre-Soviet Siberia (according to Tomsk province documents).

Osrtovsky, Yu. (1911). Siberian Jews. 
'The Code of laws' of the Russian Empire. (1838). Code 2. Part 1. № 10242.

'The Code of laws' of the Russian Empire. (1844). Code. 2. Part 1. № 18029.

Tsam, G.Ya. (1909).The history of a military-prayerful school appearance, reconstructed in 1907 and called "Soldatskaya"

Ulyanova, O. S. (2011). Jewish community of Tomsk: appearance, activity and disappearance (in the mid $19^{\text {th }}$ - in the early $20^{\text {th }}$ century).

Unpublished Doc. 35. List 4. Archive fond 3. State Archive of Tomsk Region (GATO).

Unpublished Doc. 235. List 1. Archive fond 104. State Archive of Tomsk Region (GATO).

Unpublished Doc. 235. List 4. Archive fond 3. State Archive of Tomsk Region (GATO).

Unpublished Doc. 397. List 77. Archive fond 3. State Archive of Tomsk Region (GATO).

Unpublished Doc. 714. List 2. Archive fond 233. State Archive of Tomsk Region (GATO).

Unpublished Doc. 996. List 13. Archive fond 3. State Archive of Tomsk Region (GATO).

Unpublished Doc. 1459. List 2. Archive fond 3. State Archive of Tomsk Region (GATO).

(1901, September 4).The Siberian Life.

Unpublished Doc. 1788. List 4. Archive fond 3. State Archive of Tomsk Region (GATO).

Unpublished Doc. 1789. List 1. Archive fond 6. State Archive of Tomsk Region (GATO).

Unpublished Doc. 3356. List 2. Archive fond 3. State Archive of Tomsk Region (GATO). 